\title{
Maturing Ganglioneuroma
}

National Cancer Institute

\section{Source}

National Cancer Institute. Maturing Ganglioneuroma. NCI Thesaurus. Code C42064.

A gang lioneuroma characterized by the presence of differentiating neuroblasts, maturing and mature gang lion cells. 